\title{
Wing Whiteness as an Indicator of Age, Immunocompetence, and Testis Size in the Eurasian Black-Billed Magpie (Pica pica)
}

\author{
Author(s): Guillermo Blanco and Juan A. Fargallo \\ Source: The Auk, 130(3):399-407. \\ Published By: The American Ornithologists' Union \\ URL: http://www.bioone.org/doi/full/10.1525/auk.2013.12201
}

BioOne (www.bioone.org) is a nonprofit, online aggregation of core research in the biological, ecological, and environmental sciences. BioOne provides a sustainable online platform for over 170 journals and books published by nonprofit societies, associations, museums, institutions, and presses.

Your use of this PDF, the BioOne Web site, and all posted and associated content indicates your acceptance of BioOne's Terms of Use, available at www.bioone.org/page/terms_of_use.

Usage of BioOne content is strictly limited to personal, educational, and non-commercial use. Commercial inquiries or rights and permissions requests should be directed to the individual publisher as copyright holder. 


\title{
The Auk
}

An International

Journal of Ornithology

Vol. 130 No. 3 July 2013

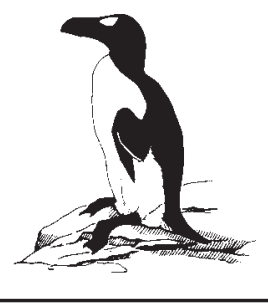

The Auk 130(3):399-407, 2013

(C) The American Ornithologists' Union, 2013.

Printed in USA.

\section{RESEARCH ARTICLES}

\section{WING WHITENESS AS AN INDICATOR OF AGE, IMMUNOCOMPETENCE, AND TESTIS SIZE IN THE EURASIAN BLACK-BILLED MAGPIE (PICA PICA)}

\author{
Guillermo Blanco and Juan A. Fargallo ${ }^{1}$ \\ Departamento de Ecología Evolutiva, Museo Nacional de Ciencias Naturales (CSIC), J. Gutiérrez Abascal 2, 28006, Madrid, Spain
}

\begin{abstract}
Determining how phenotypic traits covary within individuals can offer information on the underlying functional interactions of complex phenotypes and the mechanisms that promote them. We investigated covariation of the white wing patch of the Eurasian Black-billed Magpie (Pica pica) with age, sex, feather wear, spleen size, parasite infection, and testis size to evaluate whether this trait is indicative of individual quality. The white wing area was larger in adults than in second-year individuals, in males and females with larger spleens and lower helminth parasite burdens, and in males with larger testes. In addition, feather wear scores were positively correlated with black melanized areas at the tips of feathers. Our results suggest that wing whiteness reflects age, immune capacity, and feather quality in both sexes and reproductive potential in males. Therefore, this character may play a role in sexual selection by signaling individual quality. Received 26 October 2012, accepted 23 April 2013.
\end{abstract}

Key words: bird coloration, depigmentation, helminth, immunocompetence, melanin, Pica pica, spleen, testis.

\section{El Color Blanco del Ala como Indicador de Edad, Inmunocompetencia y Tamaño de los Testículos en la Pica pica}

RESUMEN.-Conocer la covariación de los diferentes caracteres fenotípicos dentro del individuo puede aportar información sobre las interecciones funcionales subyacentes a los fenotipos complejos y sobre los mecanismos que las promueven. En el presente estudio se ha investigado la covariación del parche blanco del ala de la Pica pica con la edad, el desgaste de las plumas, el tamaño del bazo, la parasitación y el tamaño de los testículos con el fin de evaluar si este carácter pudiera indicar calidad individual. El parche blanco del ala resultó ser más grande en adultos que en individuos de primer año, en individuos con bazos de mayor tamaño y menor carga parasitaria de helmintos y en machos con testículos más grandes. Además el desgaste de las rémiges se correlacionó positivamente con el área melanizada negra del final de la pluma. Estos resultados sugieren que el blanco del ala refleja edad, inmunocompetencia y calidad de la pluma en ambos sexos y potencial reproductor en los machos. Por lo tanto, este carácter podría jugar un papel importante en la selección sexual a través de la señalización de calidad individual.

CERTAin SUBSETS OF traits can often covary strongly within individuals and lead to complex phenotypes. The patterns of covariation among phenotypic traits reflect the degree of genetic, developmental, and/or functional associations (Pigliucci 2003, Kim et al. 2013). Coloration is one of the most diverse phenotypic traits in nature, and its function is one of the most studied subjects in behavioral ecology. Exploring how coloration is integrated with other traits may help in understanding color functionality and the action of natural selection on multivariate phenotypes (Hoekstra 2006, McGuigan et al. 2011, Pryke et al. 2012). Melanin deposition is the most common mechanism responsible for colored traits in vertebrates (Bagnara et al. 1979, Hoekstra 2006, Hubbard et al. 2010, Stoddard and Prum

${ }^{1}$ Address correspondence to this author. E-mail: fargallo@mncn.csic.es

The Auk, Vol. 130, Number 3, pages 399-4.07. ISSN 0004-8038, electronic ISSN 1938-4254. (c) 2013 by The American Ornithologists' Union. All rights reserved. Please direct all requests for permission to photocopy or reproduce article content through the University of California Press's Rights and Permissions website, http://www.ucpressjournals. com/reprintInfo.asp. DOI: 10.1525/auk.2013.12201 
2011). In birds, classical functions assigned to melanin-based phenotypes are those related to individual recognition (Dale et al. 2001), thermoregulation (e.g., Sirkiä et al. 2010), camouflage (Galeotti and Rubolini 2004, Gluckman and Cardoso 2010), photoprotection (Hadley 1972), and signaling (e.g., Senar and Camerino 1998).

The signaling function of melanin-based phenotypes is still poorly understood. A traditional view has considered the expression of melanin-based characters to be independent of nutrition and condition and, therefore, poor traits for studying the process of sexually selected mate choice (Gray 1996, McGraw and Hill 2000), even though they can signal genetic quality (Roulin and Altwegg 2007). With few exceptions (e.g., Griffith et al. 1999, Roulin and Altwegg 2007), most studies that have considered melanic coloration as a sexual ornament have focused on conspicuous melaninbased plumage as badges. In conjunction with behavior, such badges are used in inter- and intrasexual communication to provide reliable information of status; costs of production are considered minimal in comparison to possible social costs of carrying the badge (Andersson 1994, Gray 1996, Badyaev and Hill 2000). However, evidence of the influence of environmental factors on melanic feather coloration is accumulating (Griffith et al. 1999; Fitze and Richner 2002; Fargallo et al. 2007a, b; McGraw 2007), which suggests that the degree of melanic expression can be condition-dependent because of the cost of increased melanin deposition. Thus, melaninbased traits may play a role in signaling theory as initially proposed by Zahavi (1975) under the handicap principle.

Recently, it has been proposed that melanin-based phenotypes can predict immune and endocrine functions through the pleiotropic effect of the genes involved in melanogenesis (Ducrest et al. 2008). Several genes responsible for melanin-based pigmentation have been identified in vertebrates (see Hubbard et al. 2010). Among them, the melanocortin system also regulates a diverse array of physiological functions, including adrenocortical steroidogenesis and anti-inflammatory responses (Cone 2006, Ducrest et al. 2008). Relationships among melanin-based phenotypes and immunity (e.g., Gasparini et al. 2009, Jacquin et al. 2011, Parejo et al. 2011; but see González et al. 1999; Pärn et al. 2005; Fargallo et al. 2007a, b), parasite infection (e.g., Fitze and Richner 2002, Chakarov et al. 2008, Jacquin et al. 2011), testosterone levels (Fargallo et al. 2007b, Bókony et al. 2008), and corticosterone levels (Pryke et al. 2012) have been observed in birds, demonstrating in some cases and suggesting in others that melanic phenotypes can signal immune capacity and endocrine profiles.

It is common for melanin-based traits in birds to be mixed with white patches (Price and Pavelka 1996, Fitzpatrick 1998, Hegyi et al. 2008). The lack of melanin expressed in white feathers or white parts of feathers has been shown to have a clear genetic component (Garant et al. 2004) and to act as an indicator of phenotypic quality in several species (Potti and Merino 1996; Kose et al. 1999; Ruusila et al. 2001; Hanssen et al. 2006, 2008; de Heij et al. 2011). White patches may have evolved as a costly handicap of feather quality or as an amplifying handicap that reflects the individual's ability to cope with its lack of melanin without compromising survival (Hasson 1991, Fitzpatrick 1998), especially if expressed in flight feathers.

In addition to those already mentioned, another major function of melanin in feathers is to ensure their durability, protecting against abrasion and breakage (Burtt 1986, Bonser 1995). This strengthening function may be especially important in flight feathers because weakly melanized feathers are prone to wear and breakage, which increase the energetic cost of flight and the risk of predation and, thus, decrease survival (Magnhagen 1991; but see Merilä and Hemborg 2000). In addition, melanin may protect feathers against parasitic lice, in that melanin-free areas are more prone to biting by lice (Kose et al. 1999). Antimicrobial properties of melanin are also known to play a role in the integument of insects (Wilson et al. 2001) and humans (Mackintosh 2001). In birds, higher keratin lysis activity of microbes and higher feather degradability in less melanized (white) feathers than in more melanized (black) ones have been reported (Goldstein et al. 2004, Ruiz-de-Castañeda et al. 2012). Therefore, a tradeoff between feather production (including keratinization and microstructure) and melanin deposition (or a lack thereof) may partially explain variation in the expression of melanin-free feather areas (Shawkey and Hill 2006, Vágási et al. 2010, Galván 2011). Also, an interspecific positive correlation between the degree of social foraging and white plumage coloration in birds has been reported, which suggests individual benefits in social contexts (Beauchamp and Heeb 2001).

We investigated whether the white wing patch included in the black melanin-based phenotype of the Eurasian Black-billed Magpie (Pica pica; Lee et al. 2010) might provide information on age, feather quality, immunocompetence, parasite burden, and endocrine profile. Melanin-free parts of magpie flight feathers are located in the middle portion of primary feathers and do not reach the tips (Fig. 1),
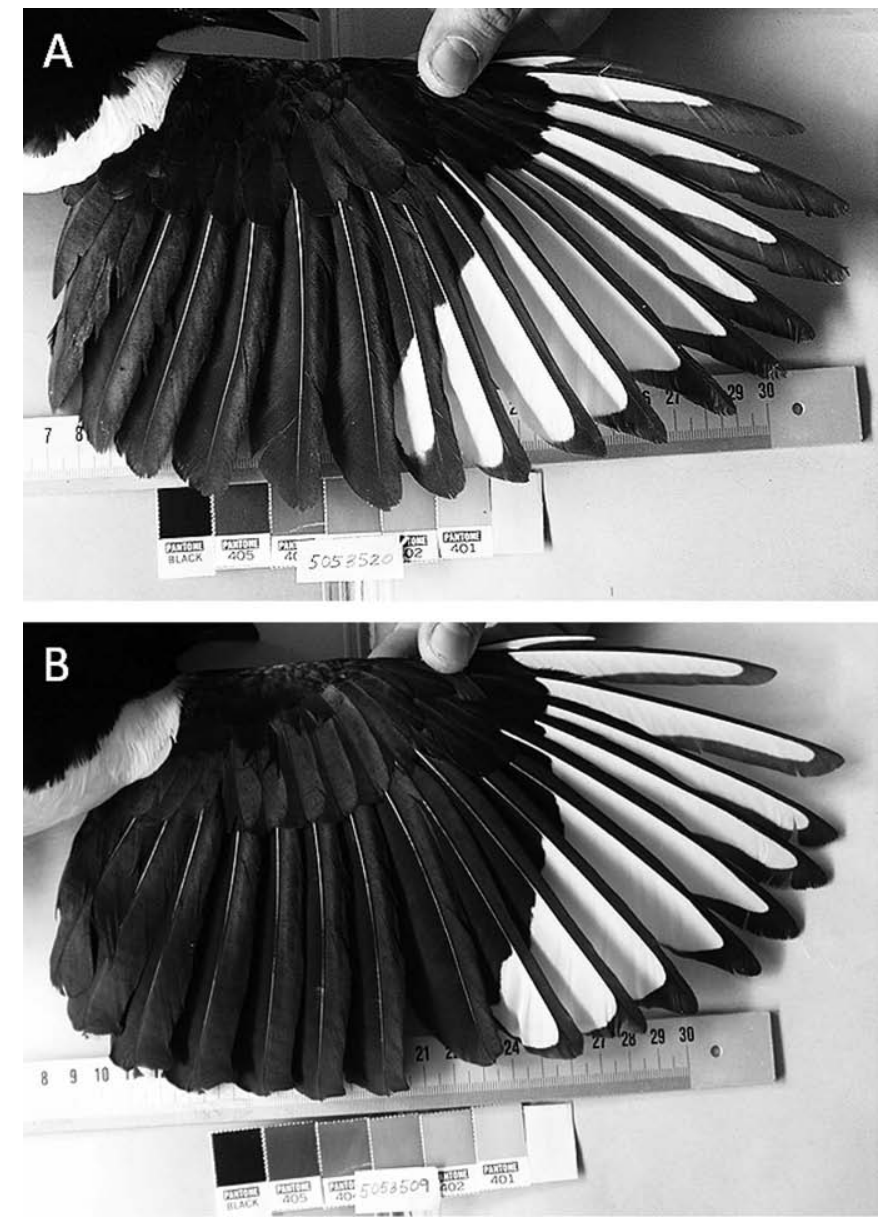

FIG. 1. Photographs of the white wing patch (dorsal view) of (A) second-year and (B) after-second-year Eurasian Black-billed Magpies. Photo by Ó. Frías. 
probably because greater abrasion at the tips of feathers (Svensson 1996) may impose important flight costs (Burtt 1986). Therefore, melanin-free areas are presumably costly to the bearer because an increase in white area toward the tips may in itself result in weaker feathers, especially if distal feather abrasion reaches the white area (Burtt 1986). We first evaluated this hypothesis by relating abrasion of feather tips to the length of the distal melanized area in wing flight feathers. We predict that if whiteness evolved as a signal of individual quality or condition, including the ability of the individual to resist feather wear, individuals with larger white wing patches (i.e., narrower black tips) should show less feather wear. Given that feathers and other structures compete for nutrients during growth and development of young in the nest, a presumably costly large white area may not develop in juveniles without subsequent maintenance costs, especially flight costs, derived from smaller melanized feathertip areas. Although wing feather tips are more melanized in juvenile Eurasian Black-billed Magpies and North American Black-billed Magpies (Pica hudsonia) (Svensson 1996, Trost 1999), no information on the total extent of the white wing patch, or on the number of feathers forming it, has been previously reported in either species, to our knowledge. In addition, depigmented plumage may bear production costs (Török et al. 2003, McGlothlin et al. 2007, Vágási et al. 2010), which have been hypothetized to derive from the ability to develop feathers with the correct microstructure, ultimately ensuring honesty (Hanssen et al. 2006, Vágási et al. 2010). On the basis of these considerations, we predicted that first-year birds should develop a smaller white area than adults.

To study immunocompetence, we measured spleen volume and parasite infection. The spleen is a major organ of the immune system of birds (John 1994), and its relative size has been shown to be related to activation of the immune system by multiple macroparasite infections; hence, it has often been used to infer the effectiveness of the immune system in birds (Møller et al. 1998, Morand and Poulin 2000, Brown and Brown 2002, Ardia 2005; but see Blanco et al. 2001, Smith and Hunt 2004). Previous results showed that a close relationship exists between nutritional condition and spleen size of the Eurasian Black-billed Magpie (hereafter "magpie"; Blanco et al. 2001). In addition, spleen volume was positively related to a quality-signaling trait (tail length) in young magpies (Blanco and de la Puente 2002). As a second estimation of immunocompetence, we measured infection by ecto- and endoparasites (helminths). If wing whiteness signals the effectiveness of the immune system, we predicted a positive correlation of wing whiteness with spleen size and a negative correlation with parasite infection. Finally, we evaluated the relationship between the extent of white wing patch and testis size in males to assess whether a melanin-based phenotype can reflect the endocrine profile. Testis size has been shown to be correlated with the production of testosterone (Denk and Kempenaers 2005, Garamszegi et al. 2005) and is considered an indicator of sperm production and sperm competition capacity (Lüpold et al. 2009, Rowe and Pruett-Jones 2011). Therefore, we expect a positive correlation between the size of the white wing patch and testis size if white wing patch reflects male quality.

\section{Methods}

General.-Magpies were collected immediately after being killed by hunters in Villatobas, Toledo, central Spain, during the breeding season (May-July) of 1998. Magpies were killed as predator controls within regional game management plans. Dead specimens were transferred for free to this research project. Birds were immediately weighed to the nearest gram, stored in plastic bags, and transported to the laboratory. Severely damaged birds were not included in the study. Birds fledged during the previous breeding season were considered second-year (SY) individuals, and all other adult birds were classified as after-second-year (ASY) individuals (see Svensson 1996). Birds were sexed by gonadal inspection.

The number of primary and secondary feathers with white coloration in the right wing was counted. Entire wings were then removed from the body, extended dorsally in a natural position (i.e., with the two outermost primaries in line with the carpometacarpus and radius), and fixed with transparent adhesive on white paper. We photocopied the wing, traced the outline of both the entire wing and the white wing area (WWA) on the paper copy, and then measured with a planimeter the areas (in $\mathrm{mm}^{2}$ ) they occupied. The measurements for both total wing and white wing areas were repeatable for a random sample of magpies $(r=0.93, F=26.27, \mathrm{df}=63, P<0.0001, n=$ $32 ; r=0.97, F=56.62, \mathrm{df}=63, P<0.0001, n=32$, respectively).

Fault bars are formed in feathers as a result of exposure to stressors, most notably starvation and poor nutrition, during feather development (Bortolotti et al. 2002, and references therein). We thus counted the number of rectrices with fault bars and the number of fault bars in the rectrices as potential indicators of environmental stress during feather growth (Blanco and de la Puente 2002). We used the tail because fault bars were more abundant than in the wing. Fault bars potentially reflect stressful environmental conditions during the previous summer-autumn for ASYs (molt period) and during growth for nestlings and for SYs (Blanco and de la Puente 2002).

An experienced veterinarian (M. Corroto, GREFA, Madrid, Spain) who was unaware of the hypotheses being tested measured (with digital calipers) the maximum length and width of the spleen and the right and left testes to the nearest $0.01 \mathrm{~mm}$ (Blanco et al. 2001). The volume $\left(\mathrm{mm}^{3}\right)$ of these organs was calculated, assuming that they had a spheroid shape. Volumes of right and left testes were summed to obtain total volume of testes (Blanco et al. 2001, Blanco and de la Puente 2002).

To test whether wing whiteness was associated with the degree of parasitism, we considered the total number of ectoparasites and helminths as independent variables. Parasites may directly influence feather quality in the case of lice that feed on feathers, and they may interact with body condition (Blanco et al. 2001) to affect feather growth (before the sampling date) and feather condition (on the sampling dates). All ectoparasites were collected before the birds were dissected by thoroughly brushing all the plumage onto white paper until no more arthropods appeared. Ectoparasites were later identified to species (Blanco et al. 2001). Helminths were removed from the alimentary tract and later identified at the phylum level as cestodes, nematodes, acanthocephalans, or trematodes (Blanco and de la Puente 2002).

Age and sex differences in wing whiteness.-We determined whether variation in WWA was dependent on the number of white feathers by exploring sex and age differences in both variables and their interaction by means of a non-hierarchical, fully saturated log linear analysis because of the categorical nature of data (three categories of the number of white wing feathers; i.e., 10, 11, or 12 feathers). The test was run beginning with the highest-order interaction and proceeded backwards until all terms and interactions retained by the model were significant $(P<0.05)$, so that dropping any of them would result in a significant lack of fit of the model. 
Melanized area at feather tip and feather wear.-To analyze the relationship between wing whiteness and feather quality, we measured (dial calipers; nearest $0.01 \mathrm{~mm}$ ) the length of the distal black area in the third primary and evaluated whether it was related to WWA and to the degree of feather wear. The length of the distal black area was defined as the distance between the feather tip and the distal part of the white area in the feather. Distal black area in the third primary was correlated with the length of the distal black area in the first, second, and fourth primaries (all $r \geq 0.89$, all $P<$ $0.0001, n=96$ ), so we used the third primary in our analyses for simplicity. The degree of feather wear of the 10 primaries was scored using the wear categories depicted in Prater et al. (1977): fresh, slightly worn, moderately worn, and very worn. We assigned the value 1 to unworn feathers ("fresh"), 2 to slightly moderately worn feathers, and 3 to very worn feathers showing very damaged vanes.

We used the sum of the wear scores as a composite measure of feather wear. Although the distribution of feather wear scores was not normal, the composite wear from all 10 primaries' indices attained normality (Kolmogorov-Smirnov test for normality of residuals from the analysis of covariance [ANCOVA], $Z=0.61, P=0.85$ ). The wear score of feathers was the dependent variable in a two-factorial ANCOVA where age and sex were factors and the black distal length of the third primary was a covariate. We also included $\log _{10}-$ transformed keel length (digital calipers; nearest $0.01 \mathrm{~mm}$ ) as a covariate to control for possible body-size effects, and date of capture (Julian date) to control for possible effects on degree of wear.

Wing whiteness and individual quality.-To test for an association between individual quality and wing whiteness, WWA was used as the dependent variable in general linear models (ANCOVA) with age, sex, $\log _{10}$-transformed body mass, past body condition (number of fault bars and numbers of feathers with fault bars), $\log _{10}$ spleen size, and number of ectoparasites and helminths as independent variables. To control for the influence of structural size on body mass and spleen volume, we defined body condition as $\log _{10}$-transformed body mass after controlling for the effect of structural size ( $\log _{10}$-transformed keel length) by including keel length as a covariate. Given that total wing area and WWA ( $\log _{10}$-transformed) were correlated (linear regression, $r=0.71, P<0.001, n=134$ ), total wing area was included as a covariate in the analyses to correct for its influence on WWA. The same analysis was repeated for males with $\log _{10}$ testis volume included as an additional independent variable. Date of capture was included in all the models to attempt to control for the possible influence of the annual cycle of testis growth and regression, as well as to control for the influence of potential seasonal variation in spleen volume. Fault bar variables were square-root transformed in all the analyses to achieve normality. Because the distribution of parasites usually follows a negative binomial distribution, the number of parasites was transformed as $y=\ln (x+0.5 k)$, where $k$ is the exponent of the negative binomial distribution; the exponent $k$ was estimated using the formula: $k=m^{2}\left(s^{2}-m\right)-1$, where $m$ is the mean and $s^{2}$ is the variance of the distribution (see Poiani et al. 2000).

The ANCOVA models were reduced to their simplest form by eliminating, in a backward stepwise manner, any independent variables or two-way interactions that did not explain significant variation in the dependent variable. We proceeded by running the model and removing variables and interactions that did not contribute significantly to variation in the dependent variable. All variables and interactions in the final model were significant, such that this represented the simplest model for explaining variability in the response
TABLE 1. Results of log-linear analyses testing interaction between the number of white wing feathers and age (second-year and after-second-year individuals) and sex of Eurasian Black-billed Magpies.

\begin{tabular}{lcrc}
\hline & df & $G$ & $P$ \\
\hline Number of white feather * age * sex & 2 & 2.04 & 0.36 \\
Number of white feather * age & 1 & 27.97 & $<0.00001$ \\
Number of white feather * sex & 1 & 2.21 & 0.33 \\
\hline
\end{tabular}

variable. The exceptions were variables forced to enter the models (i.e., date of capture, keel length, and total wing area) to control for seasonal and structural size variation. All dependant variables were normally distributed or transformed to attain normality. The model residuals were checked for normality and homoscedasticity at each step. All $P$ values refer to two-tailed tests. Partial eta squared $\left(\eta_{\mathrm{p}}{ }^{2}\right)$ was used as a measure of effect size in ANCOVA. Because some data were missing for some birds, sample sizes varied slightly among analyses. Means \pm SD are reported. All analyses were performed with the SPSS statistical package (SPSS 1990).

\section{RESULTS}

Age and sex differences in wing whiteness.-A log-linear analysis of variation in the number of white feathers with age and sex did not show a three-way interaction (Table 1). Second-year magpies have more white feathers in the wing (usually 11 feathers; i.e., 10 primaries plus the most distal secondary) than ASYs (usually 10 primaries) (Table 1 and Figures 1 and 2), but there were no differences between sexes (Table 1). The fit of the model containing these interactions was

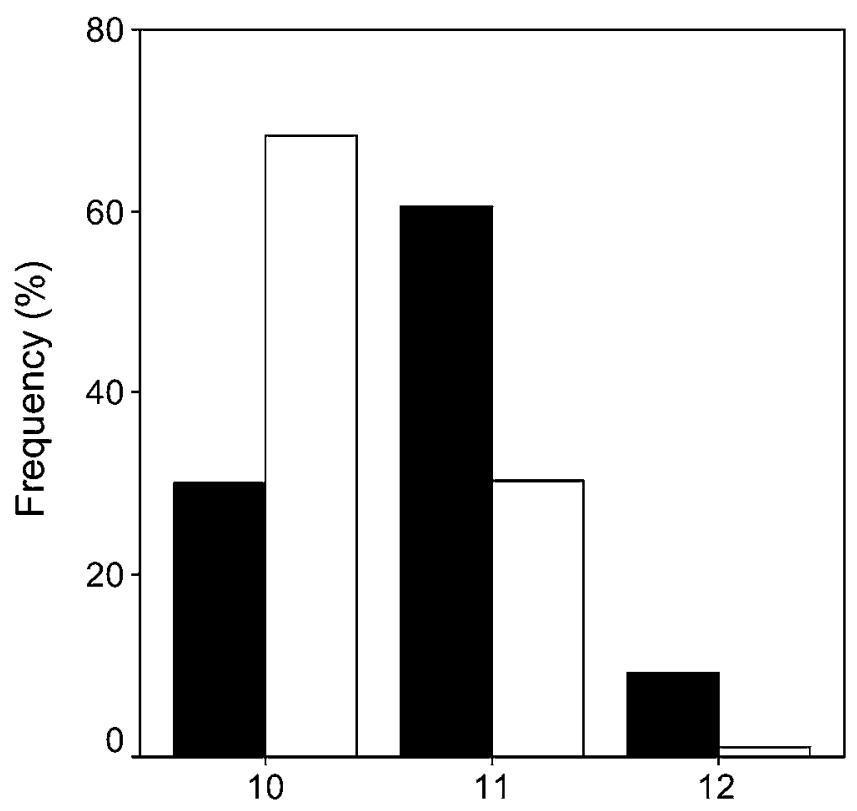

\section{Number of white wing feathers}

FIG. 2. Frequency (\%) of second-year ( $n=45$, black bars) and after-second-year ( $n=89$, white bars) Eurasian Black-billed Magpies with 10 white primaries, 11 white feathers (10 primaries plus the outermost secondary), and 12 white feathers (10 primaries plus the 2 outermost secondaries). 


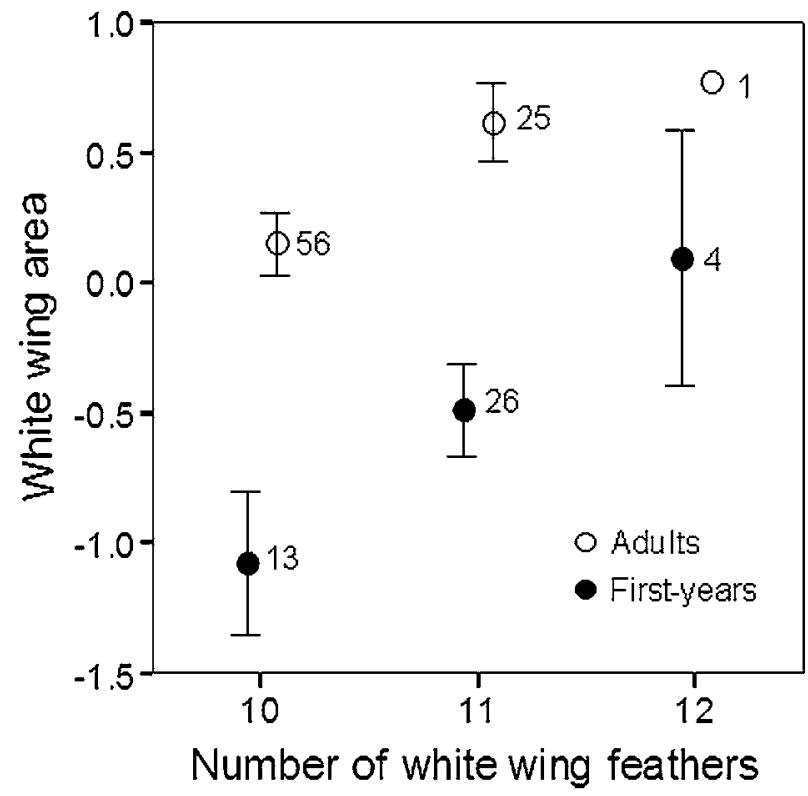

FIG. 3. Mean $( \pm \mathrm{SE})$ wing whiteness scaled to total wing area in relation to the number of white feathers in the wing of second-year (SY) and aftersecond-year (ASY) Eurasian Black-billed Magpies.

adequate (goodness-of-fit, $G=6.51 \mathrm{df}=6, P=0.37$ ). Birds with 12 white feathers usually showed a small and diffuse white spot in the distal part of the second outermost primary that never reached the tip. Despite having more white feathers, SYs had less WWA (803 \pm $87 \mathrm{~mm}^{2}, n=43: 23$ males, 20 females, mean values corrected for total wing area) than ASYs $\left(929 \pm 91 \mathrm{~mm}^{2}, n=82: 43\right.$ males, 39 females, $F=40.36, \mathrm{df}=124, P<0.0001$; Fig. 3$)$, and this area increased with the number of white feathers in each age class $(F=5.87, \mathrm{df}=124, P=$ 0.004; Fig. 3). There were no effects of $\operatorname{sex}(F=0.49, \mathrm{df}=124, P=0.48)$, nor any significant interactions between the factors (all $P>0.34$ ). This model accounted for $26 \%$ of the variance. Because WWA can be higher even though the number of white feathers might be lower, the former variable was used as a better descriptor of wing whiteness.

Wing whiteness and feather wear.-Feather wear scores were independent of age, size, sex, and capture date (all $P>0.10$ ) but varied significantly and positively with the length of the black tip of the third primary $\left(F=29.27, \mathrm{df}=81, P<0.0001, \eta_{\mathrm{p}}{ }^{2}=0.27\right.$, $r^{2}=0.30$; Fig. 4A). When included in this model, WWA did not contribute significantly to feather wear $(F=0.98, \mathrm{df}=1$ and 80 , $\left.P=0.32, \eta_{\mathrm{p}}{ }^{2}=0.013\right)$. Taking the length of the black tip out of the model, WWA was not significantly correlated with feather wear scores $\left(F=1.58, \mathrm{df}=1\right.$ and $\left.81, P=0.21, \eta_{\mathrm{p}}{ }^{2}=0.020\right)$. However, WWA and the length of the black tip were negatively and significatively correlated ( $r=-0.48, P<0.001, n=81$; Fig. 4B).

Wing whiteness and immunocompetence.-The simplest ANCOVA showed that WWA was greater in ASY than in SY birds $(F=$ $15.59, \mathrm{df}=63, P<0.0001, \eta_{\mathrm{p}}{ }^{2}=0.50$; see above), after correcting for the total wing area as a covariate $\left(F=89.47, \mathrm{df}=63, P<0.0001, \eta_{\mathrm{p}}{ }^{2}=0.24\right)$. In addition, WWA increased with spleen size $(F=10.95, \mathrm{df}=63, P=$ $0.002, \eta_{\mathrm{p}}^{2}=0.15$; Fig. $5 \mathrm{~A}$ ) and decreased as the number of helminths in the alimentary tract increased $\left(F=4.87, \mathrm{df}=63, P=0.031, \eta_{\mathrm{p}}{ }^{2}=0.08\right.$; Fig. 5B). Date of capture and keel length were included in the model to control for seasonal and structural size variation despite not being
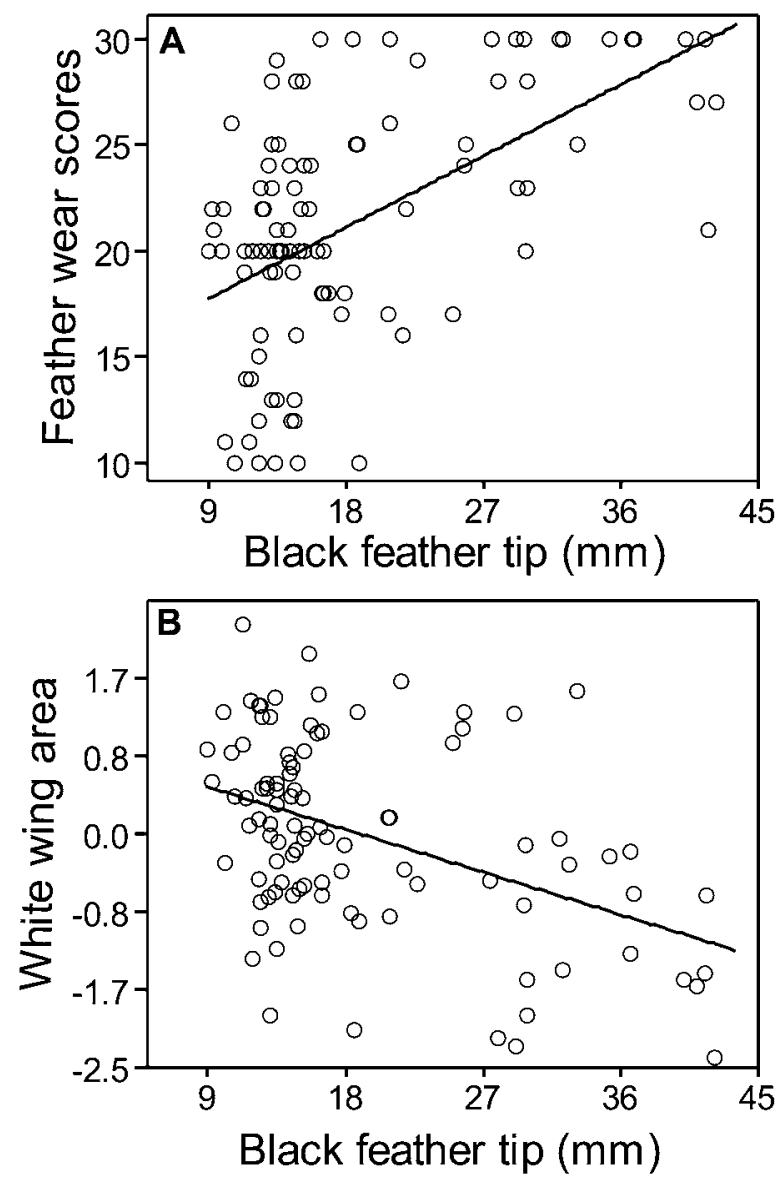

FIG. 4. Relationships between the length of the black tip of the third primary feather and (A) feather wear scores and (B) white wing area scaled to total wing area (residuals of the regression between $\log _{10}$-transformed total and white wing areas in $\mathrm{mm}^{2}$ ) of magpies.

significant (both $P>0.27$ ). The remaining variables (including the total number of fault bars and the number of feathers with fault bars) were excluded at $P>0.29$. This model explained $67.4 \%$ of the variance.

Wing whiteness and testis size.-In males, WWA showed similar significant relationships with age $\left(F=13.17, \mathrm{df}=33, P=0.001, \eta_{\mathrm{p}}{ }^{2}=\right.$ $0.32)$, total wing area $\left(F=82.70, \mathrm{df}=33, P<0.0001, \eta_{\mathrm{p}}{ }^{2}=0.75\right)$, spleen volume $\left(F=6.65, \mathrm{df}=1\right.$ and $\left.33, P=0.016, \eta_{\mathrm{p}}{ }^{2}=0.20\right)$, and number of helminths $\left(F=4.68, \mathrm{df}=33, P=0.040, \eta_{\mathrm{p}}{ }^{2}=0.15\right)$ as in the previous analysis. Testis volume contributed significantly and independently to variation in WWA $\left(F=10.73, \mathrm{df}=33, P=0.003, \eta_{\mathrm{p}}{ }^{2}=0.28\right.$; Fig. 6). Date of capture and keel length were included in the model to control for seasonal and structural size variation, but neither was significant (both $P>0.22$ ). The remaining variables (including the total number of fault bars and the number of feathers with fault bars) were excluded at $P>0.14$. This model explained $80.0 \%$ of the variance.

\section{Discussion}

Age and WWA.-In most cases, only the 10 primaries of ASYs had white areas whereas SYs had white areas in all primaries as well as in the most distal secondary (total $=11$ remiges). Both ASYs and SYs may increase their white wing area by producing one or 

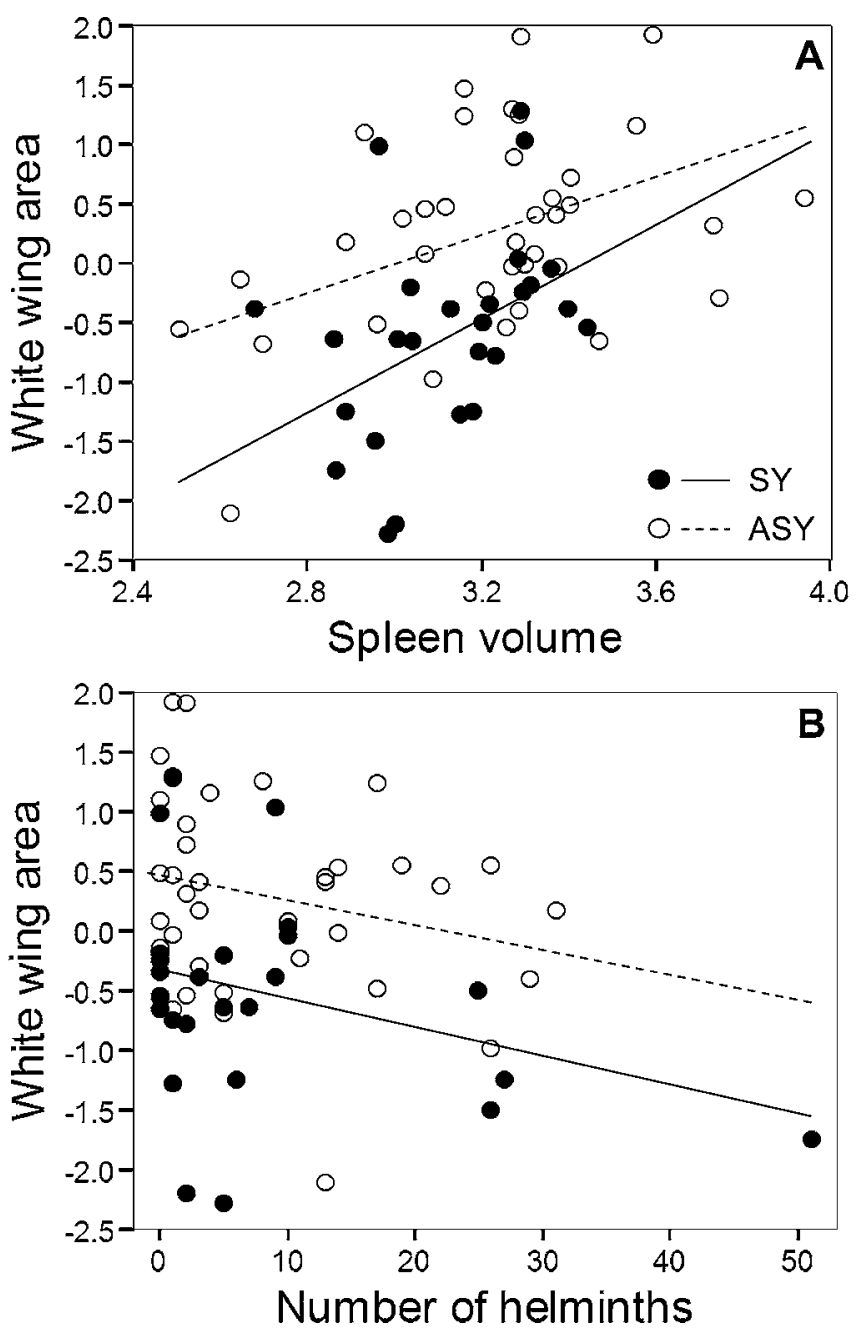

FIG. 5. Relationships between white wing area scaled to total wing area (residuals of the regression between $\log _{10}$-transformed total and white wing areas in $\mathrm{mm}^{2}$ ) and (A) $\log _{10}$ spleen volume $\left(\mathrm{mm}^{3}\right)$ and (B) number of helminths in the alimentary tract of Eurasian Black-billed Magpies. Note that these are univariate trends (see text; $S Y=$ second-year and ASY = after-second-year).

two extra white feathers. However, although SYs had more white feathers on average than ASYs, the total white area was higher in ASYs than in SYs for each particular number of white feathers.

A larger melanin-free feather area may be possible in adults that grow feathers of higher quality (i.e., more keratinized feathers; Stettenheim 2000). The SY feathers were grown while there were competing nutrient demands for the growth of other structures and organs, which perhaps resulted in a less keratinized and melanized SY feather. Hence, compared to adults, a large white area may be costly for SY birds (Vágási et al. 2010). In fact, although SY feathers had more melanized area than adults, feathers of SYs are generally more abraded than those of adults (Birkhead 1991, G. Blanco unpubl. data), which may result in heavy costs during flight (Bortolotti 2006). An alternative mechanism allowing the expression of larger white wing patches while dimishing the risk of feather breakage and/or abrasion may be to increase the number of white feathers

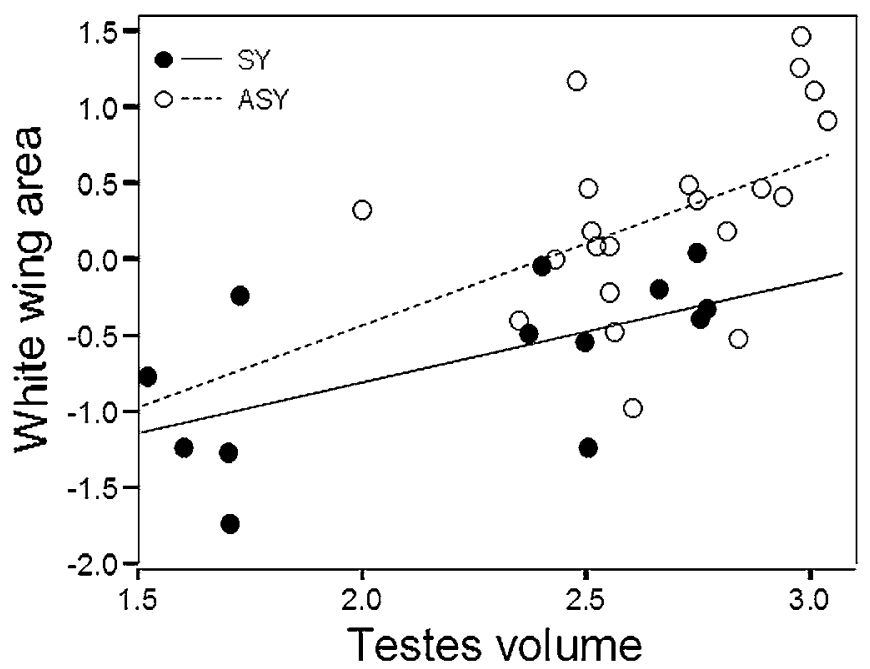

FIG. 6. Relationships between white wing area scaled to total wing area (residuals of the regression between $\log _{10}$-transformed wing and white patch areas in $\left.\mathrm{mm}^{2}\right)$ and $\log _{10}$ testis volume $\left(\mathrm{mm}^{3}\right)$ of male Eurasian Black-billed Magpies. Note that these are univariate trends (see text; $\mathrm{SY}=$ second-year and ASY = after-second-year).

rather than lengthening the white patch toward the feather tip. Therefore, SYs may develop an enlarged white wing patch by producing one white secondary rather than increasing the amount of white toward the tips of primaries (Fig. 1). Variation among ASYs in WWA may be a consequence of age and warrants further study.

The combination of an additional feather and less white area in the distal part of the feathers makes the wing patch of SYs longer and narrower than that of adults (Fig. 1). The white wing patch may thus function as an indicator of age and enable SYs to join flocks of nonbreeders (Birkhead 1991). Second-year individuals may benefit from signaling a reduced competitive capacity compared to adults (Coombs 1978, Birkhead 1991).

WWA as a signal of quality.-The white wing patch of the magpie may function as a handicap and, thus, serve as a signal of individual quality, because a large white patch may increase feather wear and breakage due to physical abrasion and consumption by ectoparasites (Bonser 1995, Kose et al. 1999, Goldstein et al. 2004). This may be especially important in birds of low quality that produce poorly keratinized feathers (Hasson 1991) with a greater likelihood of producing fault bars that are often the sites of feather breakage (Slagsvold 1982, Serrano and Jovani 2005).

The extent of the WWA were also correlated positively with spleen size and negatively with the number of helminths in the alimentary tract in both adults and SYs, which suggests that WWA may be associated with immunocompetence. John (1995) reported that bird species that showed higher parasitic helminth prevalence also had larger spleens, which suggests a role for this organ in the prevention of helminth infections. We had previously found that body condition in magpies of all age and sex classes was the variable most strongly positively correlated with spleen size (Blanco et al. 2001). Spleen size was also positively related with tail length of SY males (Blanco and de la Puente 2002). Therefore, assuming that the population that we sampled was not affected by parasites and pathogens to the point of promoting splenomegaly (Blanco 
et al. 2001), our results suggest that wing whiteness may be a true indicator of immune-system quality. Wing whiteness has been found to reflect immune capacity in other species as well (Potti and Merino 1996, Hanssen et al. 2008).

Unlike a recent interspecific study of anatids in which no significant correlation was found between testis size and white wing patches (Hegyi et al. 2008), our results showed a positive correlation between wing whiteness and testis size. Testis size is generally assumed to be an indicator of sexual behavior and fertilization capacity in birds, because sexual activity, sperm production, testosterone secretion, frequency of extrapair paternity, secondary sexual trait expression, and sperm competition often covary positively with the size of testes (Møller and Briskie 1995, Merilä and Sheldon 1999, Dunn et al. 2001, Denk and Kempenaers 2005, Garamszegi et al. 2005, Pitcher et al. 2005, Lüpold et al. 2009). The positive relationship between WWA and testis size suggests that the size of the white wing patch may contain information on reproductive quality of male magpies. On the other hand, WWA of males and females did not differ; therefore, it is no doubt the case that physiological mechanisms other than testosterone production are linked to the expression of white in the wing of magpies.

Given that the quality of both parents influences reproductive success in the magpie (Birkhead 1991), the use of the same trait for information transfer under conditions of social monogamy can account for monomorphism when traits may convey information for both sexes (Jones and Hunter 1993, Kraaijeveld et al. 2007, Hoi and Griggio 2008). Magpies are sexually dimorphic in wing whiteness, and both sexes show mate-choice behavior (Birkhead 1991). Therefore, both males and females may obtain offspring benefits (e.g., resistance genes, high levels of parental investment, or good habitat quality) by pairing with mates showing high levels of wing whiteness.

In conclusion, our correlational study shows that the variation in the melanin-based design of magpie remiges differed between young and adult individuals and was linked to other phenotypic traits that reveal information on immunocompetence and testis size in both age classes. This indicates that both sexes could select mates using this character, which reflects parasite infection status and immune capacity. In addition, by surveying this character in males, females may obtain information about a potential mate's reproductive abilities. Therefore, the white wing patch may play a role in sexual selection in both sexes. Relationships between magpie coloration and immunocompetence did not show significant interactions with age and sex. Similarly, no interaction with age class was observed in the relationship between wing whiteness and testis size. Even without knowing the causal mechanisms that promote among-character covariation, our results suggest that the patterns of covariation among these characters are maintained within age and sex classes and suggest a functional link in this subset of phenotypic traits.

\section{ACKNOWLEDGMENTS}

We are very grateful to M. P. Martín Mateo and M. Carles-Tolrás for parasite identification, M. Corroto and J. Colás for their careful measurements of organs, and J. de la Puente for measuring the birds. We thank J. Potti for his help in data analysis, and C. Lakunza for improving the English and manuscript style. Permission for killing and collecting was granted through the project 130/RN-19, "Effect of predators on small game species: Evaluating methods for the regulation of predation levels." Agreement: J. C. Castilla-La Mancha/CSIC. Funding for this work was provided by the projects CGL2007-61395/BOS and CGL2010-15726.

\section{Literature Cited}

Andersson, M. 1994. Sexual Selection. Princeton University Press, Princeton, New Jersey.

ARDiA, D. R. 2005. Cross-fostering reveals an effect of spleen size and nest temperatures on immune function in nestling European Starlings. Oecologia 145:327-334.

Badyaev, A. V., AND G. E. Hill. 2000. Evolution of sexual dichromatism: Contribution of carotenoid- versus melanin-based coloration. Biological Journal of the Linnean Society 69:153-172.

Bagnara, J. T., J. Matsumoto, W. Ferris, S. K. Frost, W. A. Turner, JR., T. T. TCHEN, AND J. D. TAYlor. 1979. Common origin of pigment cells. Science 203:410-415.

Beauchamp, G., and P. Heeb. 2001. Social foraging and the evolution of white plumage. Evolutionary Ecology Research 3:703-720.

BirkHEAD, T. R. 1991. The Magpies. T \& AD Poyser, London.

Blanco, G., And J. De la Puente. 2002. Multiple elements of the Black-billed Magpie's tail correlate with variable honest information on quality in different age/sex classes. Animal Behaviour 63:217-225.

Blanco, G., J. de la Puente, M. Corroto, A. Baz, and J. Colás. 2001. Condition-dependent immune defence in the magpie: How important is ectoparasitism? Biological Journal of the Linnean Society 72:279-286.

Bókony, V., L. Z. Garamszegi, K. Hirschenhauser, and A. LIKER. 2008. Testosterone and melanin-based black plumage coloration: A comparative study. Behavioural Ecology \& Sociobiology 62:1229-1238.

BONSER, R. H. 1995. Melanin and the abrasion resistance of feathers. Condor 97:590-591.

Bortolotti, G. R. 2006. Natural selection and avian coloration: Protection, concealment, advertisement or deception? Pages 3-35 in Bird Coloration, vol. 2: Function and Evolution (G. E. Hill and K. J. McGraw, Eds.). Harvard University Press, Cambridge, Massachusetts.

Bortolotti, G. R., R. D. Dawson, And G. L. Murza. 2002. Stress during feather development predicts fitness potential. Journal of Animal Ecology 71:333-342.

Brown, C. R., AND M. B. Brown. 2002. Spleen volume varies with colony size and parasite load in a colonial bird. Proceedings of the Royal Society of London, Series B 269:1367-1373.

BurtT, E. H., JR. 1986. An analysis of physical, physiological, and optical aspects of avian coloration with emphasis on woodwarblers. Ornithological Monographs, no. 38.

Chakarov, N., M. Boerner, and O. Krüger. 2008. Fitness in Common Buzzards at the cross-point of opposite melaninparasite interactions. Functional Ecology 22:1062-1069.

Cone, R. D. 2006. Studies on the physiological functions of the melanocortin system. Endocrine Reviews 27:736-749.

Coombs, C. J. F. 1978. The Crows: A Study of the Corvids of Europe. Batsford, London.

Dale, J., D. B. Lank, And H. K. Reeve. 2001. Signaling individual identity versus quality: A model and case studies with ruffs, queleas, and House Finches. American Naturalist 158:75-86. 
DE Hei,, M. E., L. GustafsSon, AND J. E. BROMMER. 2011. Experimental manipulation shows that the white wing patch in Collared Flycatchers is a male sexual ornament. Ecology and Evolution 1:546-555.

DenK, A. G., And B. Kempenaers. 2005. Testosterone and testes size in Mallards (Anas platyrhynchos). Journal of Ornithology 147:436-440.

Ducrest, A. L., L. Keller, And A. Roulin. 2008. Pleiotropy in the melanocortin system, coloration and behavioural syndromes. Trends in Ecology \& Evolution 23:502-510.

Dunn, P. O., L. A. Whittingham, And T. E. Pitcher. 2001. Mating systems, sperm competition, and the evolution of sexual dimorphism in birds. Evolution 55:161-175.

Fargallo, J. A., T. LAAKSONEN, E. KorpimäKI, AND K. WAKAMATSU. 2007a. A melanin-based trait reflects environmental growth conditions of nestling male Eurasian Kestrels. Evolutionary Ecology 21:157-171.

Fargallo, J. A., J. Martínez-Padilla, A. Toledano-Díaz, J. Santiago-Moreno, And J. A. Dávila. 2007b. Sex and testosterone effects on growth, immunity and melanin coloration of nestling Eurasian Kestrels. Journal of Animal Ecology 76:201-209.

Fitze, P. S., AND H. Richner. 2002. Differential effects of a parasite on ornamental structures based on melanins and carotenoids. Behavioral Ecology 13:401-407.

FITZPATRICK, S. 1998. Birds' tails as signaling devices: Markings, shape, length, and feather quality. American Naturalist 151:157-173.

Galeotti, P., ANd D. Rubolini. 2004. The niche variation hypothesis and the evolution of colour polymorphism in birds: A comparative study of owls, nightjars and raptors. Biological Journal of the Linnean Society 82:237-248.

GalváN, I. 2011. Feather microstructure predicts size and colour intensity of a melanin-based plumage signal. Journal of Avian Biology 42:473-479.

Garamszegi, L. Z., M. Eens, S. Hurtrez-Boussès, and A. P. MøLlER. 2005. Testosterone, testes size, and mating success in birds: A comparative study. Hormones and Behavior 47:389-409.

Garant, D., B. C. Sheldon, and L. Gustafsson. 2004. Climatic and temporal effects on the expression of secondary sexual characters: Genetic and environmental components. Evolution 58:634-644.

Gasparini, J., P. Bize, R. Piault, K. Wakamatsu, J. D. Blount, A.-L. Ducrest, AND A. Roulin. 2009. Strength and cost of an induced immune response are associated with a heritable melanin-based colour trait in female Tawny Owls. Journal of Animal Ecology 78:608-616.

Gluckman, T.-L., And G. C. CARDoso. 2010. The dual function of barred plumage in birds: Camouflage and communication. Journal of Evolutionary Biology 23:2501-2506.

Goldstein, G., K. R. Flory, B. A. Browne, S. Majid, J. M. IChidA, AND E. H. BurtT, JR. 2004. Bacterial degradation of black and white feathers. Auk 121:656-659.

González, G., G. Sorci, A. P. Møller, P. Ninni, C. Haussy, And F. DE LOPE. 1999. Immunocompetence and condition-dependent sexual advertisement in male House Sparrows (Passer domesticus). Journal of Animal Ecology 68:1225-1234.

Gray, D. A. 1996. Carotenoids and sexual dichromatism in North American passerine birds. American Naturalist 148:453-480.

Griffith, S. C., P. F. Owens, And T. BurKe. 1999. Environmental determination of a sexually selected trait. Nature 400:358-360.
HAdLEY, M. E. 1972. Functional significance of vertebrate integumental pigmentation. American Zoologist 12:63-76.

Hanssen, S. A., I. Folstad, and K. E. Erikstad. 2006. White plumage colouration reflects individual quality in female eiders. Animal Behaviour 71:337-343.

Hanssen, S. A., D. Hasselquist, I. Folstad, and K. E. ErikSTAD. 2008. A label of health: A previous immune challenge is reflected in the expression of a female plumage trait. Biology Letters 4:379-381.

Hasson, O. 1991. Sexual displays as amplifiers: Practical examples with an emphasis on feather decorations. Behavioral Ecology 2:189-197.

Hegyi, G., L. Z. GARAMSZEgi, AND M. Eens. 2008. The roles of ecological factors and sexual selection in the evolution of white wing patches in ducks. Behavioral Ecology 19:1208-1216.

Hoekstra, H. E. 2006. Genetics, development and evolution of adaptive pigmentation in vertebrates. Heredity 97:222-234.

Hoi, H., AND M. Griggio. 2008. Dual utility of a melanin-based ornament in Bearded Tits. Ethology 114:1094-1100.

Hubbard, J. K., J. Albert, C. Uy, M. C. Hauber, H. E. Hoekstra, AND R. J. SAfRAN. 2010. Vertebrate pigmentation: From underlying genes to adaptive function. Trends in Genetics 26:231-239.

Jacquin, L., P. Lenouvel, C. Haussy, S. Ducatez, and J. GaspaRINI. 2011. Melanin-based coloration is related to parasite intensity and cellular immune response in an urban free living bird: The feral pigeon Columba livia. Journal of Avian Biology 42:11-15.

JoHn, J. L. 1994. The avian spleen: A neglected organ. Quarterly Reviews of Biology 69:327-351.

JoHN, J. L. 1995. Parasites and the avian spleen: Helminths. Biological Journal of the Linnean Society 54:87-106.

Jones, I. L., AND F. M. HunTER. 1993. Mutual sexual selection in a monogamous seabird. Nature 362:238-239.

Kim, S. Y., J. A. Fargallo, P. Vergara, and J. MartíneZ-Padilla. 2013. Multivariate heredity of melanin-based coloration, body mass and immunity. Heredity doi.10.1038/hdy.2013.29.

Kose, M., R. MÄNd, AND A. P. Møller. 1999. Sexual selection for white tail spots in the Barn Swallow in relation to habitat choice by feather lice. Animal Behaviour 58:1201-1205.

Kraaijeveld, K., F. J. L. Kraaijeveld-Smit, and J. Komdeur. 2007. The evolution of mutual ornamentation. Animal Behaviour 74:657-677.

Lee, E., H. Lee, J. Kimura, and S. Sugita. 2010. Feather microstructure of the Black-billed Magpie (Pica pica sericea) and Jungle Crow (Corvus macrorhynchos). Journal of Veterinary Medical Science 72:1047-1050.

Lüpold, S., G. M. Linz, J. W. Rivers, D. F. Westneat, and T. R. BIRKHEAD. 2009. Sperm competition selects beyond relative testes size in birds. Evolution 63:391-402.

Mackintosh, J. A. 2001. The antimicrobial properties of melanocytes, melanosomes and melanin and the evolution of black skin. Journal of Theoretical Biology 211:101-113.

Magnhagen, C. 1991. Predation risk as a cost of reproduction. Trends in Ecology \& Evolution 6:183-186.

McGlothlin, J. W., D. L. Duffy, J. L. Henry-Freeman, and E. D. KETTERSON. 2007. Diet quality affects an attractive white plumage pattern in Dark-eyed Juncos (Junco hyemalis). Behavioural Ecology and Sociobiology 61:1391-1399. 
MCGRAw, K. J. 2007. Dietary mineral content influences the expression of melanin-based ornamental coloration. Behavioral Ecology 18:137-142.

McGraw, K. J., And G. E. Hill. 2000. Differential effects of endoparasitism on the expression of carotenoid- and melanin-based ornamental coloration. Proceedings of the Royal Society of London, Series B 267:1525-1531.

McGuigan, K., L. Rowe, And M. W. Blows. 2011. Pleiotropy, apparent stabilizing selection and uncovering fitness optima. Trends in Ecology \& Evolution 26:22-29.

Merilä, J., And C. Hemborg. 2000. Fitness and feather wear in the Collared Flycatcher Ficedula albicollis. Journal of Avian Biology 31:504-510.

Merilä, J., And B. C. Sheldon. 1999. Testis size variation in the Greenfinch Carduelis chloris: Relevance for some recent models of sexual selection. Behavioural Ecology and Sociobiology 45:115-123.

Møller, A. P., AND J. V. Briskie. 1995. Extra-pair paternity, sperm competition and the evolution of testis size in birds. Behavioral Ecology and Sociobiology 36:357-365.

Møller, A. P., P. Christe, J. Erritzøe, and J. Mavarez. 1998. Condition, disease and immune defence. Oikos 83:301-306.

Morand, S., ANd R. Poulin. 2000. Nematode parasite species richness and the evolution of spleen size in birds. Canadian Journal of Zoology 78:1356-1360.

Parejo, D., N. Silva, É. Danchin, And J. M. Avilés. 2011. Informative content of melanin-based plumage colour in adult Eurasian Kestrels. Journal of Avian Biology 42:49-60.

PÄrn, H., J. T. Lifjeld, AND T. Amundsen. 2005. Female throat ornamentation does not reflect cell-mediated immune response in Bluethroats Luscinia s. svecica. Oecologia 146:496-504.

Pigliucci, M. 2003. Phenotypic integration: Studying the ecology and evolution of complex phenotypes. Ecology Letters 6:265-272.

Pitcher, T. E., P. O. Dunn, And L. A. Whittingham. 2005. Sperm competition and the evolution of testes size in birds. Journal of Evolutionary Biology 18:557-567.

Poinni, A., A. R. Goldsmith, And M. R. Evans. 2000. Ectoparasites of House Sparrows (Passer domesticus): An experimental test of the immunocompetence handicap hypothesis and a new model. Behavioral Ecology and Sociobiology 47:230-242.

Potti, J., AND S. Merino. 1996. Decreased levels of blood trypanosome infection correlate with female expression of a male secondary sexual trait: Implications for sexual selection. Proceedings of the Royal Society of London, Series B 263:1119-1204.

Prater, A. J., J. H. Marchant, and J. Vuorinen. 1977. Guide to the Identification and Ageing of Holartic Waders. British Trust for Ornithology, Tring, United Kingdom.

Price, T., ANd M. PavelKa. 1996. Evolution of a colour pattern: History, development, and selection. Journal of Evolutionary Biology 9:451-470.

Pryke, S. R., L. B. Astheimer, S. C. Griffith, and W. A. ButteMER. 2012. Covariation in life-history traits: Differential effects of diet on condition, hormones, behavior, and reproduction in genetic finch morphs. American Naturalist 179:375-390.

Roulin, A., AND R. Altwegg. 2007. Breeding rate is associated with pheomelanism in male and with eumelanism in female Barn Owls. Behavioral Ecology 18:563-570.
Rowe, M., And S. Pruett-Jones. 2011. Sperm competition selects for sperm quantity and quality in the Australian Maluridae. PLoS ONE 6:e15720.

Ruiz-de-Castañeda, R., E. H. Burtt, JR., S. González-Braojos, AND J. MorenO. 2012. Bacterial degradability of an intrafeather unmelanized ornament: A role for feather-degrading bacteria in sexual selection? Biological Journal of the Linnean Society 105:409-419.

Ruusila, V., H. Pöysä, AND P. RunKo. 2001. Female wing plumage reflects reproductive success in Common Goldeneye Bucephala clangula. Journal of Avian Biology 32:1-5.

Senar, J. C., And M. CAmerino. 1998. Status signalling and the ability to recognize dominants: An experiment with siskins (Carduelis spinus). Proceedings of the Royal Society of London, Series B 265:1515-1520.

SERRANO, D., AND R. Jovani. 2005. Adaptive fault bar distribution in a long-distance migratory, aerial forager passerine? Biological Journal of the Linnean Society 85:455-461.

Shaw Key, M. D., ANd G. E. Hill. 2006. Significance of a basal melanin layer to production of non-iridescent structural plumage color: Evidence from an amelanotic Steller's Jay (Cyanocitta stelleri). Journal of Experimental Biology 209:1245-1250.

Sirkï̈, P. M., M. Virolainen, And T. LaAksonen. 2010. Melanin coloration has temperature-dependent effects on breeding performance that may maintain phenotypic variation in a passerine bird. Journal of Evolutionary Biology 23:2385-2396.

Slagsvold, T. 1982. Sex, size, and natural selection in the Hooded Crow Corvus corone cornix. Ornis Scandinavica 13:165-175.

Smith, K. G., AND J. L. Hunt. 2004. On the use of spleen mass as a measure of avian immune system strength. Oecologia 138:28-31.

SPSS. 1990. SPSS Advanced Statistics User's Guide. SPSS, Chicago, Illinois.

Stettenheim, P. R. 2000. The integumentary morphology of modern birds-An overview. American Zoologist 40:461-477.

Stoddard, M. C., AND R. O. Prum. 2011. How colorful are birds? Evolution of the avian plumage color gamut. Behavioral Ecology 22:1042-1052.

Svensson, L. 1996. Guía para la identificación de los Passeriformes Europeos. SEO/BirdLife, Madrid.

TöröK, J., G. Hegyi, And L. Z. Garamszegi. 2003. Depigmented wing patch size is a condition-dependent indicator of viability in male Collared Flycatchers. Behavioral Ecology 14:382-388.

Trost, C. H. 1999. Black-billed Magpie (Pica hudsonia). In Birds of North America Online (A. Poole, Ed.). Cornell Lab of Ornithology, Ithaca, New York. Available at bna.birds.cornell.edu/bna/ species/389.

VÁGÁsi, C. I., P. L. PAP, AND Z. BARTA. 2010. Haste makes waste: Accelerated molt adversely affects the expression of melaninbased and depigmented plumage ornaments in House Sparrows. PLoS ONE 5:e14215.

Wilson, K., S. C. Cotter, A. F. Reeson, And J. K. Pell. 2001. Melanism and disease resistance in insects. Ecology Letters 4:637649.

ZAHAVI, A. 1975. Mate selection-A selection for a handicap. Journal of Theoretical Biology 53:205-214.

Associate Editor: M. T. Murphy 